\title{
Effect of Plant Botanicals on Growth of Mycoflora Associated with Pigeon Pea Seeds
}

\author{
Barkha Bharti* and Asha Sinha \\ Department of Mycology and Plant Pathology, Institute of Agricultural Sciences, \\ Banaras Hindu University-221005, Uttar pradesh, India \\ *Corresponding author:
}

\begin{abstract}
A B S T R A C T
Keywords

Pigeon Pea, Seed, Mycoflora,

Botanicals, in vitro inhibition

Article Info

Accepted:

20 July 2019

Available Online:

10 August 2019

A study was conducted to determine the mycoflora associated with pigeon pea cultivar MA6 and effect of botanicals on growth of mycoflora. The dominant fungi observed on pigeon pea cultivar MA6 seed were Rhizopus stolonifer, Aspergillus niger, A. flavus, Penicillium citrinum, P. rubrum, Alternaria alternata, A. solani, Curvularia lunata, Fusarium oxysporium. Among the treatments, the sulphate and nitrate treated seeds showed the less number of fungi isolated in comparison to untreated seeds. The nature of fungal flora had changed with prolongation of storage period of pigeonpea seeds. Effect of plant botanicals at $15 \%$ concentration on the radial growth of mycoflora found that leaf extract of neem (Azadiracta indica) inhibited the growth of Aspergillus niger upto a maximum of $54.85 \%$ and Penicillium citrinum was least inhibited. At the same leaf extract concentration of $O$. sanctum treatment, it was observed to be most inhibitory to Aspergillus flavus which inhibited the fungal growth up to $37.93 \%$ and leaf extract of C. longa was observed to be most inhibitory to Rhizopus stolonifer inhibiting the fungal growth up to $31.86 \%$.
\end{abstract}

\section{Introduction}

Pigeon pea (Cajanus cajan L.) belonging to the family Fabaceae is grown all over the world have played a significant role in the evolution of human civilization. India is the world's largest producer of pigeon pea and generates $67.28 \%$ of total global production. The cultivation area in India was 56.02 lakh hectares in 2016-17 and the production level was 32.90 lakh tonnes at $587 \mathrm{~kg} / \mathrm{ha}$ (Ackermann, 1998, Chakravarthy at el., 2002). Myanmar is the second largest producer of pigeon pea with $11.76 \%$ of global production followed by lesser producers Malawi, Kenya, Tanzania and Haiti.

Damages due to pests and diseases and the consequent loses, both in quality and quantity of grains, that always take place in storage are attributable to a number of factor, temperature and relative humidity being of prime importance. Seed carry a wide range of microorganism either externally or internally or both and these organism become active in favourable conditions and cause considerable 
damage to the seed and several diseases on the crop rose from them in various ways. Some of the seed borne mycoflora might reduce the germinability of seeds when planted or result in disease in the growing plant. Losses due to storage fungi in the conditions prevailing in India may be as high as 30 per cent of the total harvest (Neeergaard, 1977).

Fungi growing on stored seeds are well known to produce metabolites toxic to other organisms including domestic animals and man (mycotoxins). Aflatoxins may cause serious disorders in the human beings or animals, when consumed, including liver damage and even cancer. Some other fungi producing mycotoxins includes Pencillium rubrum, $P$. pupurogenum (rubratoxins), $P$. viridicatum, $\quad P$. citrinum (citrinin), $P$. cyclopium (penicillic acid);Aspergillus clavatus, A.terreus, A.patulum, A. palitans; Fusarium oxysporum, $F$. moniliforme, $F$. roseum (Zearalenone).

Although, chemical fungicides have been used since long time for treatment of the seeds, they are well known for their nontarget effects over the mankind and their hazards have forced the scientists of the era to rethink of their use particularly with the theme of 'sustainable agriculture'. Consequently, people associated with plant protection sciences tried to search a suitable alternative of the agrochemicals, particularly pesticides, in the return of higher plants and their products. Due to high potency of antimicrobial properties, non phytotoxic nature and easy availability with no side effects, the higher plants and herbs have been used to control several diseases of human being and animals. The application of higher plants and herbal products against phytopathogenic microorganism in general and in storage were given much attention now-a-days to control pathogenic microorganism causing severe damage to the crop and food commodities. The volatile and nonvolatiles fraction of higher plants have been given much emphasis due to their high fungi toxic properties against parasitic, saprophytic and pathogenic fungi. The volatiles do not leave any residue, hence there is least chance of residual toxicity in treatment of food commodities (Asthana et al., 1986, Chakravarthy, et al., Singh, 2010, Sinha et al., 1999, Pandey et al., 2012, Devi and Chhetry, 2012). Keeping in view the above gap in research effect of plant botanicals on mycoflora associated with pigeon pea seeds was studied.

\section{Materials and Methods}

\section{Isolation of seed fungi}

Isolation of fungi associated with pigeon pea cultivar MA6 seeds were carried out for a period of nine months periodically from July 2012 to March 2013 following Agar plate method (Musket and Malone, 1941), Blotter Method (Doyer, 1938) and the techniques recognized by International Seed Testing Association.

\section{Preparation of pure culture and storage of fungi}

The pure culture of the target fungi were obtained through hyphal tip culture technique wherein tip of the fungal mycelium was transferred on to $3 \%$ water agar medium poured in petriplate after solidification. The plates were incubated at $25 \pm 1{ }^{\circ} \mathrm{C}$ for 5-7 days. After development of fungal colony single hyphal tip were cut out and placed on another fresh plate of water agar medium with the help of stereomicroscope and incubated again $25 \pm 1{ }^{\circ} \mathrm{C}$ for $5-7$ days to obtain pure culture and the pure cultures were maintained on nutrient agar slant at $25 \pm 1^{\circ} \mathrm{C}$ and stored in deep freezer. 


\section{Seed treatment with plant botanicals}

Different concentration of three plant botanicals viz., turmeric (Curcuma longa), tulsi (Ocimum sanctum) and leaves of neem (Azadiracta indica) were prepared by methods suggested by Bhat and Sivaprakashan (Bansal and Sobti, 1990) and evaluated their potential to control mycelial growth of dominant seed associated fungi viz., Alternaria alternata, Fusarium roseum, Aspergillus niger, Aspergillus flavus, Curvularia lunata and Rhizopus stolonifer. The percent inhibition in growth due to treatment of various botanicals at different concentration was computed as followed: alternata, A. solani, Curvularia lunata, Fusarium oxysporium and white sterile mycelium.

\section{Blotter Method}

Fungi that were isolated from potassium sulphate, potassium nitrate and untreated control of pigeon pea cultivar MA6 seeds stored at 0 days i.e. fresh seed, 90, 180 and 270 days from July 2012 to April 2013 by Blotter method were presented in table 4, 5 , and 6 respectively. A total 14 to 15 fungal species were isolated from the pigeon pea seeds at different period of storage from July 2012 to April 2013.

Mycelial growth inhibition $(\%)=\mathrm{dc}-\mathrm{dt} / \mathrm{dc} \times 100$ The common fungus isolated by blotter paper method were Rhizopus stolonifer, Aspergillus Where $\mathrm{dc}=$ average diameter of fungal colony in control, and $\mathrm{dt}=$ average diameter of fungal colony in treatment group.

\section{Results and Discussion}

\section{Isolation of fungi}

Isolation of fungi associated with pigeon pea cultivar MA6 seeds were carried out for a period of nine months periodically from July 2012 to March 2013 following Agar plate method and blotter method

\section{Agar plate method}

Fungi that were isolated from potassium sulphate, potassium nitrate and untreated control of pigeon pea cultivar MA6 seeds stored at 0 days i.e. fresh seed, 90, 180 and 270 days from July 2012 to April 2013 by agar plate method were presented in table 1,2 and 3 respectively. The dominant fungi that were observed irrespective of storage duration and treatment by this method were Rhizopus stolonifer, Aspergillus niger, A. flavus, Penicillium citrinum, P. rubrum, Alternaria niger, A. flavus, Penicillium citrinum, $P$. rubrum, and other dominant fungi like Alternaria alternata, A. solani, Curvularia lunata, Fusarium oxysporium, and White sterile mycelium.

Among the treatment the sulphate and nitrate treated seeds show the less number of fungi isolated in comparison to untreated seeds. Total 15 fungal species were isolated from pigeon pea seeds during different period of storage from July 2012 to April 2013 by Blotter method.

The nature of fungal flora had changed with prolongation of storage period of pigeonpea seeds. The fungi were recorded as Aspergillus niger, A. flavus, A. terreus, Penicillium citrinum, $P$. rubrum which were partially replaced by Rhizopus spp., Alternaria alternata, A. solani, Curvularia lunata, Trichoderma viride, Fusarium spp., Drechslera sorokinia. The dominant fungi were recorded from fresh seeds like Aspergillus niger, A. flavus, Penicillium citrinum, Alternaria alternata and Rhizopus stolonifer. 
Newly harvested seed were generally infected with a variety of fungi which were contaminated in field contaminants. The numbers of seed borne fungi increased along with the period of storage found variation in fungus of stored seed in different storage period.

The dominant fungi on fresh seeds were recorded like Alternaria alternata, A. solani, Rhizopus spp., Curvularia lunata, Trichoderma viride, Fusarium spp. and Drechslera spp. theses fungi were replaced by storage fungi viz. Aspergillus niger, A. flavus, A. terreus and Penicillium citrinum. It had been observed that the field fungi decreased along with increase the storage time. It was evident from observation that maximum fungi were recorded in rainy season, summer season and lesser number of fungal species was recorded in winter season. The field fungi declined under storage due to development of storage fungi under the ecological condition prevailing during the storage latter can thrive better. Among the species Aspergillus niger, A. flavus, A. terious, Penicillium spp. and rhizopus spp. were the most dominant.

Decreasing in number of fungal species during storage had also been reported by other workers (Reddy et al., 1983; Vijay lakshmi et al., 1985; Paul mishra et al., 1992; Singh, 1999; Singh, 2006 and Singh et al., 2011). Fungi infection during storage produces mycotoxins was reported by (Al-Yahya, 1999).

\section{Comparison between Agar plate and Blotter technique}

It was observed that more fungi were isolated by blotter technique in comparison to agar plate method. Many workers (Roy, 2010; Tondon, 1977; Upadhyay and Singh, 1978; Singh et al., 1999 and Singh et al., 2011) had reported that more fungi were isolated by blotter technique than agar plate method and this shows that the slow growing fungi and weak competitors could not grow in agar plate due to competition.

Some fungi were observed only on the Blotter technique viz. Alternaria spp. and Drechslera spp. This indicates that the slow growing fungi could not be grown successfully in culture plates during competition with fast growing fungi. The other possible reasons could be the selective nature of culture media that had not favored the growth of some other fungi.

\section{Comparisons among the treatments and untreated seeds}

The present study reveals that more fungi were isolated from nitrate treated seeds in comparison to sulphate treated seeds, untreated seeds in comparison to sulphate treated seed and untreated seed in comparison to nitrate treated seeds.

Effect of plant botanicals on the radial growth of selected mycoflora of seeds in vitro

Mycoflora of the seeds treated with three plant botanicals, viz., Azadiracta indica (neem), Ocimum sanctum (tulsi) and Curcuma longa (turmeric).

\section{Azadiracta indica Leaf Extract}

The data pertaining to Azadiracta indica leaf extract treatment on the extent of mycelia growth inhibition was presented in table (Table 7)

It is evident from table 7 that the fungal species most inhibited by leaf extract of neem (Azadiracta indica) include Aspergillus niger (54.85), Aspergillus flavus (54.02), A.terreus (52.10) at $15 \%$ concentration. 
Table.1 Fungi isolated from fresh Cajanus cajan seeds by agar plate method

\begin{tabular}{|l|c|c|c|c|}
\hline \multicolumn{5}{|c|}{ Treated seed (Potassium sulphate) } \\
\hline \multicolumn{1}{|c|}{ No. of days } & 0 & 90 & 180 & 270 \\
\hline Fungus spp & & & & + \\
\hline Rhizopus stolonifer & + & + & - & + \\
\hline Aspergillus niger & + & + & + & - \\
\hline Aspergillus flavus & + & + & - & - \\
\hline Aspergillus terreus & - & - & - & + \\
\hline Aspergillus candidus & + & + & - & - \\
\hline Alternaria solani & - & - & - & + \\
\hline Alternaria alternata & + & - & + & - \\
\hline Fusarium roseum & + & - & + & - \\
\hline Fusarium oxysporum & - & - & - & - \\
\hline Penicillium rubrum & + & + & - & + \\
\hline Penicillium citrinum & + & + & + & + \\
\hline Curvularia lunata & + & + & + & - \\
\hline Drechslera sorokinia & - & - & - & - \\
\hline Trichoderma spp. & - & - & - & + \\
\hline White sterile mycelium & - & - & + & \\
\hline
\end{tabular}

Table.2 Fungi isolated from fresh Cajanus cajan seeds by agar plate method

\begin{tabular}{|l|c|c|c|c|}
\hline \multicolumn{5}{|c|}{ Treated seed (Potassium nitrate) } \\
\hline \multicolumn{1}{|c|}{ No of days } & 0 & 90 & 180 & 270 \\
\hline Fungus spp & & & & \\
\hline Rhizopus stolonifer & - & - & - & + \\
\hline Aspergillus niger & - & + & + & + \\
\hline Aspergillus flavus & - & + & - & + \\
\hline Aspergillus terreus & - & - & - & + \\
\hline Aspergillus candidus & - & + & - & - \\
\hline Alternaria solani & - & - & - & - \\
\hline Alternaria alternata & - & + & + & + \\
\hline Fusarium roseum & - & + & + & - \\
\hline Fusarium oxysporum & - & - & - & - \\
\hline Penicillium rubrum & - & + & - & - \\
\hline Penicillium citrinum & - & + & + & + \\
\hline Curvularia lunata & - & + & + & - \\
\hline Drechslera sorokinia & - & - & - & - \\
\hline Trichoderma spp. & - & - & - & - \\
\hline White sterile mycelium & - & + & + & + \\
\hline
\end{tabular}


Table.3 Fungi isolated from fresh Cajanus cajan seeds by agar plate method:

\begin{tabular}{|l|c|c|c|c|}
\hline \multicolumn{5}{|c|}{ Untreated seed(control) } \\
\hline \multicolumn{1}{|c|}{ No of days } & 0 & 90 & 180 & 270 \\
\hline Fungus spp & & & & + \\
\hline Rhizopus stolonifer & + & + & + & + \\
\hline Aspergillus niger & + & + & + & + \\
\hline Aspergillus flavus & + & + & + & - \\
\hline Aspergillus terreus & - & + & + & + \\
\hline Aspergillus candidus & + & + & + & - \\
\hline Alternaria solani & - & - & - & + \\
\hline Alternaria alternata & + & + & + & + \\
\hline Fusarium roseum & + & + & + & + \\
\hline Fusarium oxysporum & + & + & + & + \\
\hline Penicillium rubrum & + & + & + & + \\
\hline Penicillium citrinum & + & + & + & + \\
\hline Curvularia lunata & + & + & + & - \\
\hline Drechslera sorokinia & - & - & - & + \\
\hline Trichoderma spp. & - & - & + & + \\
\hline White sterile mycelium & - & + & + & \\
\hline
\end{tabular}

Table.4 Fungi isolated from Cajanus cajan seeds by Blotter paper method

\begin{tabular}{|l|c|c|c|c|}
\hline \multicolumn{5}{|c}{ Treated seed (Patassium sulphate) } \\
\hline No of days & 0 & 90 & 180 & 270 \\
\hline Fungus spp & & & & \\
\hline Rhizopus stolonifer & + & - & - & - \\
\hline Aspergillus niger & + & + & + & + \\
\hline Aspergillus flavus & - & - & - & + \\
\hline Aspergillus terreus & + & + & + & + \\
\hline Aspergillus candidus & - & - & + & - \\
\hline Alternaria solani & + & + & - & - \\
\hline Alternaria alternata & + & - & - & - \\
\hline Fusarium roseum & + & - & - & - \\
\hline Fusarium oxysporum & - & - & - & - \\
\hline Penicillium rubrum & - & - & + & - \\
\hline Penicillium citrinum & + & + & - & - \\
\hline Curvularia lunata & + & + & + & - \\
\hline Drechslera sorokinia & - & + & - & + \\
\hline Trichoderma spp. & - & - & - & - \\
\hline White sterile mycelium & + & - & + & + \\
\hline
\end{tabular}


Table.5 Fungi isolated from Cajanus cajan seeds by Blotter paper method:

\begin{tabular}{|l|c|c|c|c|}
\hline \multicolumn{4}{|c|}{ Treated seed (Patassium nitrate) } \\
\hline \multicolumn{1}{|c|}{ No of days } & 0 & 90 & 180 & 270 \\
\hline Fungus spp & & & & \\
\hline Rhizopus stolonifer & - & + & + & + \\
\hline Aspergillus niger & + & + & + & + \\
\hline Aspergillus flavus & - & - & - & + \\
\hline Aspergillus terreus & + & + & + & + \\
\hline Aspergillus candidus & + & - & - & - \\
\hline Alternaria solani & + & + & + & + \\
\hline Alternaria alternata & + & - & + & - \\
\hline Fusarium roseum & + & - & - & - \\
\hline Fusarium oxysporum & - & - & - & - \\
\hline Penicillium rubrum & - & - & + & - \\
\hline Penicillium citrinum & + & + & - & + \\
\hline Curvularia lunata & + & + & + & + \\
\hline Drechslera sorokinia & + & + & + & + \\
\hline Trichoderma spp. & + & - & - & - \\
\hline White sterile mycelium & - & - & - & + \\
\hline
\end{tabular}

Table.6 Fungi isolated from fresh Cajanus cajan seeds by Blotter paper method

\begin{tabular}{|l|c|c|c|c|}
\hline \multicolumn{5}{|c|}{ Untreated seed(control) } \\
\hline \multicolumn{1}{|c|}{ No of days } & 0 & 90 & 180 & 270 \\
\hline Fungus spp & & & & \\
\hline Rhizopus stolonifer & + & + & + & + \\
\hline Aspergillus niger & + & + & + & + \\
\hline Aspergillus flavus & + & + & + & + \\
\hline Aspergillus terreus & + & - & + & - \\
\hline Aspergillus candidus & + & + & + & - \\
\hline Alternaria solani & + & + & + & + \\
\hline Alternaria alternata & + & + & + & + \\
\hline Fusarium roseum & + & + & + & + \\
\hline Fusarium oxysporum & + & + & + & + \\
\hline Penicillium rubrum & + & + & + & + \\
\hline Penicillium citrinum & + & + & + & + \\
\hline Curvularia lunata & + & + & + & + \\
\hline Drechslera sorokinia & + & - & + & + \\
\hline Trichoderma spp. & + & + & + & + \\
\hline White sterile mycelium & - & + & + & - \\
\hline
\end{tabular}


Table.7 In vitro effect of Azadiracta indica on the radial growth (percent inhibition) of selected mycoflora of Cajanus cajan cultivar MA6

\begin{tabular}{|c|c|c|c|c|c|c|}
\hline \multirow{3}{*}{ Fungal spp. } & \multicolumn{6}{|c|}{ Concentration } \\
\hline & \multicolumn{2}{|c|}{5} & \multicolumn{2}{|c|}{10} & \multicolumn{2}{|c|}{15} \\
\hline & $\begin{array}{l}\text { Average colony } \\
\text { diameter } \\
(\mathbf{m m})\end{array}$ & $\begin{array}{l}\text { Percent growth } \\
\text { diameter } \\
(\mathbf{m m})\end{array}$ & $\begin{array}{l}\text { Average colony } \\
\text { diameter } \\
(\mathbf{m m})\end{array}$ & $\begin{array}{l}\text { Percent growth } \\
\text { diameter } \\
(\mathbf{m m})\end{array}$ & $\begin{array}{l}\text { Average colony } \\
\text { diameter } \\
(\mathrm{mm})\end{array}$ & $\begin{array}{l}\text { Percent growth } \\
\text { diameter } \\
(\mathrm{mm})\end{array}$ \\
\hline Aspergillus flavus & 79 & 9.19 & 60.05 & 30.97 & 40 & 54.02 \\
\hline Alternaria alternata & 69.5 & 20.11 & 54 & 37.83 & 42.30 & 51.37 \\
\hline Aspergillus niger & 67 & 22.98 & 53.1 & 39.06 & 39.28 & 54.85 \\
\hline Aspergillus terreus & 65.05 & 25.22 & 57.30 & 34.13 & 41.67 & 52.10 \\
\hline $\begin{array}{l}\text { Penicillium } \\
\text { citrinum }\end{array}$ & 78 & 10.34 & 71 & 18.39 & 59.28 & 31.16 \\
\hline Rhizopus stolonifer & 81.49 & 6.33 & 73 & 16.09 & 59 & 32.18 \\
\hline Control & \multicolumn{2}{|c|}{87} & \multicolumn{2}{|c|}{87} & \multicolumn{2}{|c|}{87} \\
\hline
\end{tabular}

*At the time when colony diameter of fungi in any of the respective treatments including control was $87 \mathrm{~mm}$. The inoculating disc size (i.e. $5 \mathrm{~mm}$ ) was substracted from the colony diameter of all the treatments. 
Table.8 In vitro effect of Ocimum sanctum on the radial growth (percent inhibition) of selected mycoflora of Cajanus cajan variety MA6 (in vitro)

\begin{tabular}{|c|c|c|c|c|c|c|}
\hline \multirow{3}{*}{ Fungal spp. } & \multicolumn{6}{|c|}{ Concentration } \\
\hline & \multicolumn{2}{|c|}{5} & \multicolumn{2}{|c|}{10} & \multicolumn{2}{|c|}{15} \\
\hline & $\begin{array}{l}\text { Average colony } \\
\text { diameter } \\
(\mathrm{mm})\end{array}$ & $\begin{array}{l}\text { Percent growth } \\
\text { diameter } \\
(\mathrm{mm})\end{array}$ & $\begin{array}{l}\text { Average colony } \\
\text { diameter } \\
(\mathrm{mm})\end{array}$ & $\begin{array}{l}\text { Percent growth } \\
\text { diameter } \\
(\mathrm{mm})\end{array}$ & $\begin{array}{l}\text { Average colony } \\
\text { diameter } \\
(\mathrm{mm})\end{array}$ & $\begin{array}{l}\text { Percent growth } \\
\text { diameter } \\
(\mathbf{m m})\end{array}$ \\
\hline Aspergillus flavus & 80.98 & 6.91 & 72.32 & 16.87 & 54 & 37.93 \\
\hline Alternaria alternata & 86 & 1.14 & 76 & 12.64 & 55 & 36.78 \\
\hline Aspergillus niger & 81 & 6.89 & 78 & 10.34 & 76 & 12.64 \\
\hline Aspergillus terreus & 85 & 2.29 & 80 & 8.04 & 77 & 11.49 \\
\hline $\begin{array}{l}\text { Penicillium } \\
\text { citrinum }\end{array}$ & 84 & 3.89 & 79 & 12.19 & 65 & 25.28 \\
\hline Rhizopus stolonifer & 84 & 3.79 & 76 & 12.64 & 67 & 22.98 \\
\hline Control & \multicolumn{2}{|c|}{87} & \multicolumn{2}{|c|}{87} & \multicolumn{2}{|c|}{87} \\
\hline
\end{tabular}

*At the time when colony diameter of fungi in any of the respective treatments including control was $87 \mathrm{~mm}$.

The inoculating disc size (i.e. $5 \mathrm{~mm}$ ) was substracted from the colony diameter of all the treatments 
Table.9 In vitro effect of Curcuma longa on the radial growth (percent inhibition) of selected mycoflora of Cajanus cajan variety MA6

\begin{tabular}{|c|c|c|c|c|c|c|}
\hline \multirow{3}{*}{ Fungal spp. } & \multicolumn{6}{|c|}{ Concentration } \\
\hline & \multicolumn{2}{|c|}{5} & \multicolumn{2}{|c|}{10} & \multicolumn{2}{|c|}{15} \\
\hline & $\begin{array}{l}\text { Average colony } \\
\text { diameter } \\
(\mathbf{m m})\end{array}$ & $\begin{array}{l}\text { Percent growth } \\
\text { diameter } \\
(\mathrm{mm})\end{array}$ & $\begin{array}{l}\text { Average colony } \\
\text { diameter } \\
(\mathrm{mm})\end{array}$ & $\begin{array}{l}\text { Percent growth } \\
\text { diameter } \\
(\mathrm{mm})\end{array}$ & $\begin{array}{l}\text { Average colony } \\
\text { diameter } \\
(\mathbf{m m})\end{array}$ & $\begin{array}{l}\text { Percent growth } \\
\text { diameter } \\
(\mathrm{mm})\end{array}$ \\
\hline Aspergillus flavus & 83.67 & 3.82 & 80.39 & 7.59 & 79 & 9.19 \\
\hline Alternaria alternata & 81.35 & 6.49 & 78.58 & 9.67 & 75.85 & 12.81 \\
\hline Aspergillus niger & 79.29 & 8.86 & 77.05 & 11.43 & 74.98 & 13.81 \\
\hline Aspergillus terreus & 77.20 & 11.40 & 76.98 & 11.51 & 72.59 & 16.56 \\
\hline $\begin{array}{l}\text { Penicillium } \\
\text { citrinum }\end{array}$ & 73.80 & 16.08 & 69.29 & 20.35 & 63.93 & 28.51 \\
\hline Rhizopus stolonifer & 69.20 & 20.67 & 65.09 & 25.18 & 59.28 & 31.86 \\
\hline Control & \multicolumn{2}{|c|}{87} & \multicolumn{2}{|l|}{87} & \multicolumn{2}{|c|}{87} \\
\hline
\end{tabular}

*At the time when colony diameter of fungi in any of the respective treatments including control was $87 \mathrm{~mm}$.

The inoculating disc size (i.e. $5 \mathrm{~mm}$ ) was subtracted from the colony diameter of all the treatments. 
However, Penicillium citrinum was least inhibited by leaf extract of Azadiracta indica at this concentration (31.16). The inhibitory effect of leaf extract of $A$. indica continued to be maximum on the radial growth of Aspergillus niger (39.06) and A. flavus (30.97) at $10 \%$ concentration. It was least inhibitory to Penicillium citrinum (18.39) and Aspergillus niger were inhibited to 22.98 at $5 \%$ concentration. However fungi not inhibited at this concentration include Alternaria alternata, Penicillium citrinum and Rhizopus stolonifer. Neem was found most effective in controlling pathogen in pigeon pea stem blight (Upadhyay et al., 2012), neem seed extract reduces flower and pod damage with increased yield of bean (Rouf and Sardar, 2011).

\section{Ocimum sanctum leaf extract}

At $15 \%$ concentration, the leaf extract of O.sanctum was observed to be most inhibitory to Aspergillus flavus inhibiting the fungal growth up to $37.93 \%$. At $10 \%$ concentration, maximum effect was observed on Aspergillus flavus (16.87\% inhibition). However, only single fungal species, viz., Aspergillus flavus was inhibited by the leaf extract of $O$. sanctum at $5 \%$ concentration to a small extent $6.91 \%$ (Table-4). O. sanctum showed fungicidal property against Fusarium oxysporum and Rhizoctonia solani (Upadhyay et al., 2012).

\section{Curcuma longa leaf extract}

At $15 \%$ concentration, the leaf extract of $C$. longa was observed to be most inhibitory to Rhizopus stolonifer inhibiting the fungal growth up to $31.86 \%$. At $10 \%$ concentration, maximum effect was observed on Rhizopus stolonifer (25.18\% inhibition). However, only single fungal species, viz., Rhizopus stolonifer was inhibited by the leaf extract of $C$. longa at $5 \%$ concentration to a small extent to $20.67 \%$
(Table 5). The extract of curcuma longa was found to inhibit Aspergillus flavus and Aspergillus niger in green gram (Swami and Alane, 2013).

In the present study it was found that a total of 15 mycoflora were associated with pigeon pea cultivar MA6. The fugal mycoflora associated was vared with the storage duration of the seed. Among the treatments with botanicals, extract of need inhibited the radial growth of Aspergillus niger by 54.85, Ocimum sanctum Leaf Extract of O.sanctum Aspergillus flavus inhibiting the fungal growth up to 37.93 and Curcuma longa leaf extract of Rhizopus stolonifer up to $31.86 \%$.

\section{Acknowledgement}

First author is grateful to Head, Department of Mycology and Plant Pathology, Institute of Agricultural Sciences, Banaras Hindu University for providing laboratory facilities. The authors are also grateful to the teaching and non teaching staff of the Department for their kind help and cooperation and valuable suggestions.

\section{References}

Al-Yahya, S.A (1999). Change of fungal infection during wheat storage at different condition. Arab Univ.J.Agric. Sci. 7:531-545

Ackermann, A.(1998). Mycoflora of South African barley and malt. J. Amer. Soc. Brew. Chem.56:169-176.

Al-Yahya, S.A (1999). Change of fungal infection during wheat storage at different condition. Arab Univ. J. Agric. Sci. 7:531-545

Chakravarthy, C.N., Thippeswamy, B., Krishanappa, M. (2002). Seed mycoflora of pigeonpea in Karnataka. Plant Disease Research.17(1):135-137.

Devi, Ranjana. Tongbram. and Chhetry, GKN.(2012). Evaluation of antifungal activities of certain plant against Fusarium udum Butler causing wilt in pigeonpea (Cajanus cajan (L.) Millsp.) International 
Journal of Scientific and Research Publications. 2 (6): 2250-3153

Doyer, L.C. (1938). Manual for determination of the seed borne disease. Wageninges: International Seed Testing Association. 59: 33.

Muskett, A.E (1948). Technique for the examination of seed for the presence of seedborne fungi. Trans. Br. Mycol. Soc. 30:74-83.

Neergaard, P. (1977). Seed pathology, I, the Macmillan Press Ltd., London and Basingstoke.

Pandey, K. Abhay., Palnib, Uma. T. and Nijendra, N. Tripathia (2012). Evaluation of Clausena pentaphylla (Roxb.) DC oil as a fungi. wileyonlinelibrary.com.

Paul, M.C. and Mishra, R.R (1992a). Studies on seed mycoflora of maize I. Seasional variation in mycoflora. Crop. Res. (Suppl.):225-232.

Rouf, F. M. A. AND Sardar, M. A. (2011). Effect of crude seed extract of some indigenous plants for the control of legume pod borer (maruca vitrata f.) on country bean. Bangladesh J. Agril. Res. 36(1): 41-50.

Reddy, A. S. and Reddy, S. M. (1983). Influence of the seed moisture on fungal succession on seeds of Sesamum indicum. Seed Research. 10(2): 120-124.

Singh, G.K. (1999). Studies on seed borne fungi of mungbean (Vigna radiate L.) during storage and their control, M.Sc.(Ag.) Thesis, Banaras Hindu University, Varansi,U.P. India.

Singh, K.; Singh, A. K. and Singh, R. P. (2010). Detection of seed mycoflora of chickpea
(Cicer arietinum). Ann. Pl. Protec. Sci., 13 (1): 1-4.

Singh, S.N. (1992). Effect of fungicidal treatment on microflora and viability of forage cowpea seeds during storage. Proceedings and viability of the $44^{\text {th }}$ Annual Meeting of Indian Phytopathological Society, Bhavnagar, Dec. 30, 1991 to Jan. 2,1992. Indian Phytopath. (suppl.) 43/44: LIX (Abs.).

Singh, U.; Kabir, A.; Sonia, A. and Singh, N. K. (2011). Screening of mycoflora infesting on some North Indian fast food. Biosciences, Biotechnology Research Asia. 8(2): 861864.

Sinha, A., Singh, S.K and Quaiser, J. (1999). Seed mycoflora of French bean and its control by means of fungicides. Tropenlandwirt 100: 59-67.

Swami, C. S. and Alane, S. K.(2013). Efficacy of some botanicals against seed - borne fungi of green gram (phaseolus aureus roxb.) Bioscience Discovery, 4(1):107-110.

Tandon, R. H. and Dwivedi, R. S. (1977). Effect of some fungicides on seed borne mycoflora and seed germination of stored Barley. Proc. $64^{\text {th }}$ Indian, Sci. Congr., 7576.

Upadhyay, R. S. and Singh, D. B. (1978). Seed mycoflora and seed treatments with fungicides. 29(1): 171-181.

Vijaylakshimi, M. and Rao, A. S. (1985). Fungal infection of sunflower seeds under different condition of storage. Indian Phytopath., 38(2): $315-318$.

\section{How to cite this article:}

Barkha Bharti and Asha Sinha. 2019. Effect of Plant Botanicals on Growth of Mycoflora Associated with Pigeon Pea Seeds. Int.J.Curr.Microbiol.App.Sci. 8(08): 2290-2301. doi: https://doi.org/10.20546/ijcmas.2019.808.266 